\author{
Military Technical College \\ Kobry El-Kobbah, \\ Cairo, Egypt.
}

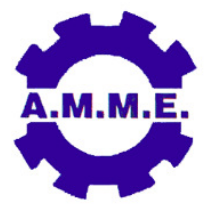

\author{
$17^{\text {th }}$ International Conference \\ on Applied Mechanics and \\ Mechanical Engineering.
}

\title{
A MULTI-STAGE SUPPLY CHAIN SYSTEM CONTROLLED BY KANBAN
}

\author{
M. A. Amer ${ }^{\star}$, E.-A.Attia ${ }^{\dagger}$ and S. Baioumy ${ }^{\ddagger}$
}

\begin{abstract}
In reasons of the new working conditions and globalization, manufacturing organizations seek to reduce their production costs. One of the factors that affect production costs is the supply chain and inventorying costs. This research presents a model of multi-stage supply chain system that operates under just-in-time (JIT) policy and supplies a fixed quantity of finished products to single customer, at a fixed time interval. Raw materials enter into the manufacturing system from two different channels. The first is brought to a consolidation centre where several items from several long-distance suppliers are collected according to single ordering policy, divided into small shipments, and redirected according to multi-ordering policy to the manufacturing system. The second type includes raw materials that are brought from JIT delivery suppliers according to the multi-ordering policy. Inbound logistics of raw materials are managed by third-party logistics (3PL) firms to coordinate and consolidate the transportation flow. The deliveries of raw material from suppliers, the work-in-process in the production stages, and the finished goods are all controlled by kanbans. For this supply chain system, the batch size and the number of batches in each stage that is to be shipped by kanbans, and the total quantity over one period are to be determined optimally. The supply chain system is modelled as a nonlinear integer programming (NLIP) problem.
\end{abstract}

\section{KEYWORDS}

Long-distance JIT supply chain, consolidation strategy, JIT purchasing, milk run, thirdparty logistics (3PL), joint replenishment problem (JRP), kanban.

MSc. Student, Mechanical Engineering department, Faculty of engineering (Benha), Benha University, Benha, Egypt. (mahaabdelhameed@yahoo.com).

† Assistant professor, Mechanical Engineering Department, faculty of engineering (Shoubra), Benha University, Cairo, Egypt. (elawady.attia@feng.bu.edu.eg).

‡ Assistant professor, Mechanical Engineering department, Faculty of engineering (Benha), Benha University, Benha, Egypt. (sohier.bayuomi@bhit.bu.edu.eg). 


\section{INTRODUCTION}

In today's global competitive environment, companies have realized that significant cost savings through the integration of inventory control and delivery policies throughout their supply chains ([1] and [2]). Just-in-time (JIT) manufacturing permits the organization to realize this goal by increasing the efficiency of production, decreasing the level of wasted materials, time, and effort involved in production processes [3]. Kanban (pull system), JIT purchasing and JIT distribution are considered the most important features to apply JIT. Kanban system is considered an efficient operational mechanism to implement the JIT philosophy. Kanban is a scheduling and information system that enables users to determine what to produce, how to produce, and how much to produce [4]. Wang and Sarker [3] explained that if a supply chain system consists of only two plants, it forms one kanban stage and it can be known as single-stage supply chain system (SSSCS). If it comprises more than two plants, and they are in series, it is called multi-stage supply chain system (MSSCS). If it consists of more than two plants, and they form an assembly tree, it is called assembly-type supply chain system (ATSCS).

In order to coordinate and integrate inventory management activities within the supply chain, companies adopt just in time purchasing (JITP) techniques [5]. Finding reliable suppliers that are willing to deliver frequent small quantities with specific quality attributes is considered the most severe problem associated with applying JITP process technology ([6] and [7]). Freight transportation plays a major role in every modern supply chain [8] and it can be considered an efficient approach in reducing freight transportation costs [9]. Freight consolidation can be defined as the consolidation of many small shipments into a larger one to be dispatched on the same vehicle [9]. Milk Run is a type of consolidation and it gives a large group of potential outcomes of consolidating freight transport activities and thus using transport capacity efficiently [10]. Milk-run method permits the joint procurement of multiple stock keeping units (SKUs) from different suppliers located in close physical proximity [11], where the buyer purchases small lots of materials placed in kanban containers at regular and short intervals [12].

However, freight transportation issues for long-distance JIT supply chain systems differ from original JIT systems and become more complex. In this context, supply chains have operated consolidation strategy in order to overcome the problems associated with long-distance JIT supply chain. Consolidation strategy can be implemented by building Supply Logistics Centres (SLC) or hubs operated by third Party Logistics service providers (3PLs) situated near the manufacturing systems [13]. The consolidation centre breaks large shipments down into smaller quantities that the plant needs, releases the provider of transport crates, boxes, and bags, places the components in the reusable containers of the plant, and transport them either to plant receiving or directly to the point of use [13]. Consolidation centres provide both leanness and agility for partners in the supply chain [14].

This paper proposes a mechanism by which an organization can coordinate its purchasing and production functions and create an integrated plan that dictates order and production quantities throughout a multi-stage supply chain system that is controlled by kanban mechanism. 


\section{LITERATURE REVIEW}

Kanban systems play an important role in the production control that they tie various manufacturing processes together and improve the operations of the production process [15]. A literature review on just-in-time (JIT) manufacturing systems and kanban operations can be found in ([16], [17], [18], and [19]). Many researchers have developed models with different methodologies. Wang and Sarker [15], [3], [20], Sarker and Balan [21][22] have developed nonlinear programming models for optimizing the number of kanbans with the objective of minimizing the total cost of (single stage supply chain system (SSSCS), multi stage supply chain system (MSSCS) and assembly-type supply chain system (ATSCS)).

The problem associated with ordering policy for raw materials, to meet the requirements of a production facility in order to deliver finished products demanded by outside buyers at fixed interval points, has been discussed by Golhar and Sarker [23], Sarker and Parija [24][25], Khan and Sarker [26], Parija and Sarker [27], Rahman and Sarker [28], Sarker and Khan [29], Sarker and Jamal [30] and Nori and Sarker [31]. Their objective was to determine an optimal or near-optimal ordering policy for procurement of raw materials and the manufacturing batch size so as to minimize the total cost.

Joint replenishment problem (JRP) has attracted many researchers since the early work of Silver [32]. In the category of integrated inventory models for the (buyervendor coordination with JIT considerations; Khouja [33], Cárdenas-Barrón [34], Woo et al. [35], Banerjee and Banerjee [36] have derived the optimal replenishment decisions for both vendor and buyers. Many authors as Çetinkaya and Lee [37], Moon et al. [1], Çetinkaya and Bookbinder [38], Chen and Sarker [39] have considered transportation decisions with different polices and strategies. Others such as Çetinkaya and Lee [37], Moon et al. [1] have considered transportation decisions for outbound distribution warehouse operated by a third party logistics provider. Çetinkaya and Bookbinder [38] have applied shipment consolidation with quantity policy and time policy. Chen and Sarker [39] have extended traditional multivendor single-buyer (MVSB) model to multivendor single-buyer vehicle-routing problem (MVSB-VRP).

Most of past works in modelling and optimization of supply chain systems have so far partially considered the aspects of material procurement policies and joint replenishment problem (JRP); long-distance JIT supply chain systems and consolidation centres; JIT distribution, milk run and third-party logistics (3PL) on multi-stage Supply chains controlled by kanban. The current paper attempts to capture a more realistic situation by combining these aspects. It considers a configuration of supply chain system with multiple suppliers and single customer, two manufacturers that form a kanban stage and a consolidation centre.

\section{PROBLEM DESCRIPTION}

This study builds a mathematical model for a multi-stage supply chain shown by Fig. 1 where raw materials are replenished from two different flow channels. Multi-stage supply chain procures raw materials of type $h$ from outside long-distance suppliers 
and it procures also raw materials of type $j$ from JIT delivery suppliers. There are three cases for materials of type j: case1: follows milk run strategy, case 2: single-raw material brought from single supplier, and the third case: single supplier delivers more than one type of raw material. The manufacturing plants process these different materials into a single type of finished product, stores them in a finished goods warehouse, and finally delivers them in fixed quantities to single customer at a fixedtime interval. The raw materials that are replenished from outside long-distance suppliers are received in consolidation centre according to single ordering policy. In this consolidation centre, raw materials that are replenished from outside longdistance suppliers are divided up into multiple equal-size shipment lots and delivered to input buffer of assigned plant $p$ according to multi-ordering policy in order to provide the required quantity of raw materials of type $h$ in one production cycle. The other type of raw materials is procured from JIT delivery suppliers. JIT delivery suppliers deliver multiple equal-size shipment lots deliveries to the input buffer of assigned plant $p$ according to (multi-ordering policy).

In this study an integrated multi-stage supply chain controlled by kanban is considered. In this supply chain system, production at plant $N+1$ is first triggered by final demand and production in plant $N$ is triggered by demand of plant $N+1$. Triggering production process in plant $N+1$ requires consumption of full containers of (semi-finished products, raw materials of type $j$ and $h$ ) that are located in input buffer of plant $N+1$, when the first semi-finished product from the full container is used the withdrawal kanbans are detached and put in the withdrawal kanban post. The withdrawal kanbans in the post are collected periodically at fixed interval of time and brought to the output buffer of plant $N$ where full containers of semi-finished products are located and to consolidation centre where full containers of raw materials of type $h$ are located. Fig. 1 shows a configuration of multi-stage supply chain system.

In the output buffer of plant $N$, the production-ordering kanbans are detached from the full containers of semi-finished products and placed in production-ordering kanban post which triggers the production process at plant $N$. Whereas withdrawal kanbans that are detached from empty containers in plant $N+1$ are attached to full containers of semi-finished products in the output buffer of plant $N$ and to full containers of raw materials of type $h$ and $j$ that are located in consolidation centre and brought in turn to plant $N+1$ and so on. With the same concept these processes are repeated throughout the system until it reaches plant 1.

First, a mathematical model is built for multi-stage supply chain system. Relying on this model, the ordering policy for the suppliers, the batch size, the number of batches that is to be shipped by kanbans, and the total quantity of products to be produced in each stage over one period and delivering policy for the customer is obtained.

\section{MODEL FORMULATION}

\section{Assumptions}

1. The plant has a general meaning, which may be a city, a plant, shop or a machine. It is considered as a unit, no matter how many facilities are installed at a location; 


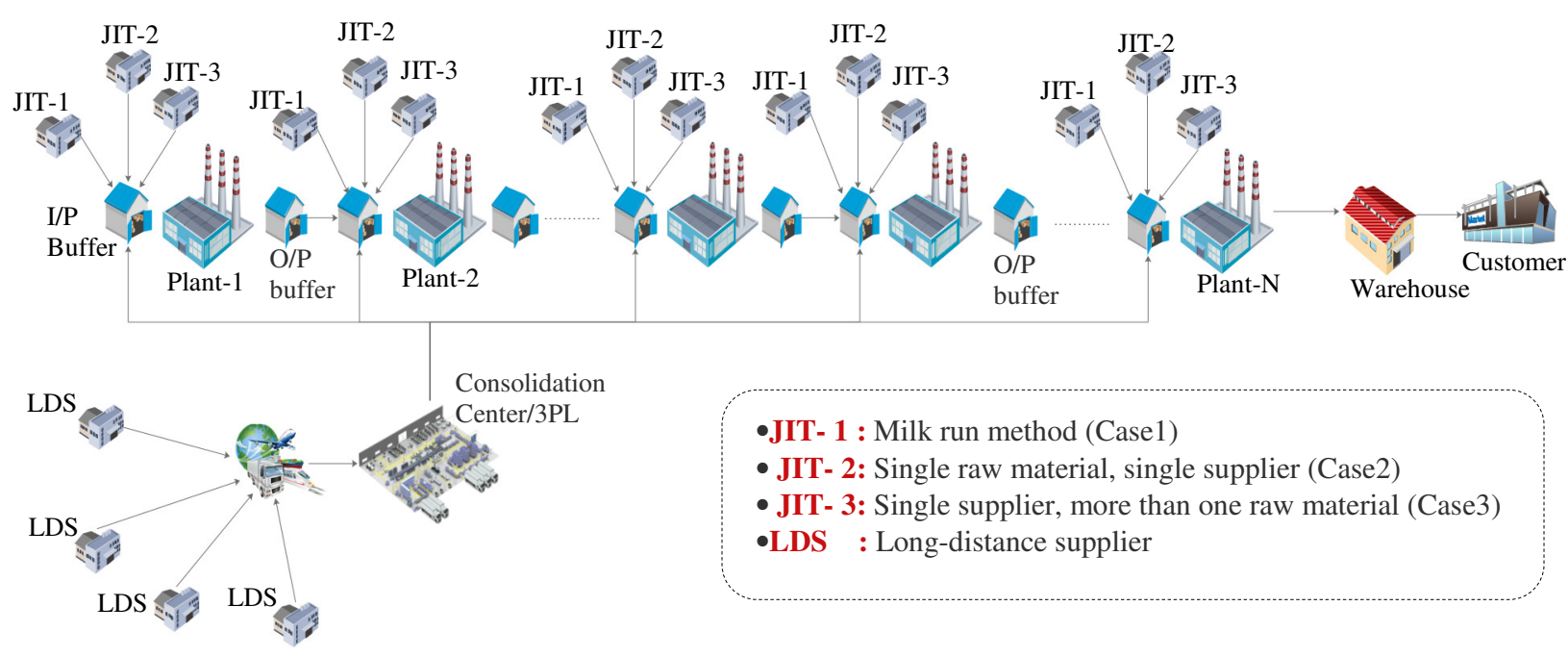

Fig.1. Configuration of multi-stage supply chain system.

2. The demand of each product in the company is known with a constant rate;

3. The production rate of each plant is known and it is larger than demand rate;

4. The total quantity of products at each stage over a period is constant;

5. The various facilities (consolidation centre- manufacturing plants-input/output buffers) are in close proximity to each other.

6. Transportation of parts from JIT-suppliers to the manufacturer is undertaken by milk-run method but the vehicle routing problem associated with milk run trips is not considered in this research;

7. Shortages and delays are not permitted.

\section{Indices:}

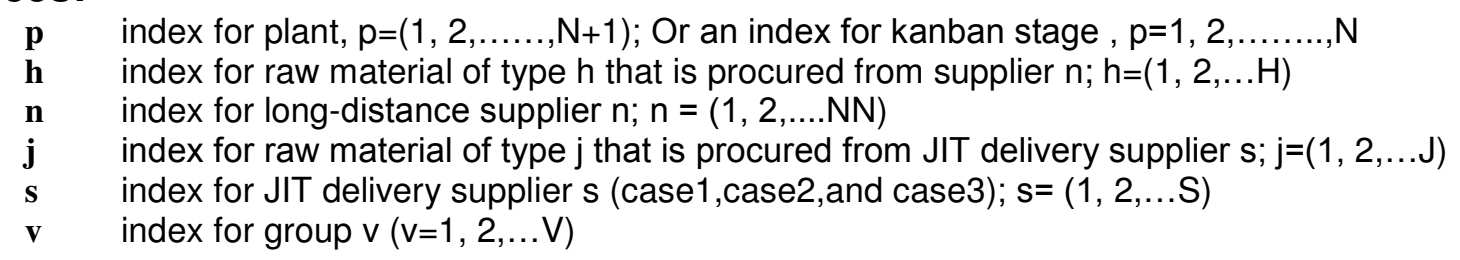

\section{Parameters:}

$\mathbf{D}_{\mathbf{h n}, \mathbf{p}} \quad$ Demand of raw material of type $h$ that is procured from supplier $n$ to be manufactured in assigned plant $p$ in period $\mathrm{T}$, units /year.

$\mathbf{D 1}_{\mathbf{j s v}, \mathbf{p}}$ Demand of raw material of type $j$ (case 1 ) that is procured from supplier $s$ to be manufactured in assigned plant $p$ in period $\mathrm{T}$, units /year.

$\mathbf{D 2}{ }_{\mathbf{j s}, \mathbf{p}}$ Demand of raw material of type $j$ (case 2) that is procured from supplier $s$ to be manufactured in assigned $p$ in period $T$, units /year.

$\mathbf{D 3}_{\mathbf{j s}, \mathbf{p}} \quad$ Demand of raw material of type $j$ (case 3) that is procured from supplier sto be manufactured in assigned plant $p$ in period $\mathrm{T}$, units /year.
HSI1 $_{\text {js,p }}$ Holding cost of raw material of type $j$ (case 2) that is held input buffer of assigned plant $p, \$ /$ unit/year.

Hs Holding cost of inventory of semifinished parts in output buffer of assigned plant $p$ and at input buffer of plant $p+1, \$ /$ unit/year.

HSI js,p $_{\text {js }}$ Holding cost of raw material of type $j$ (case 3) that is held input buffer of assigned plant $p, \$ /$ unit/year.

$\mathbf{H s}_{\mathbf{f}} \quad$ Holding cost of finished goods inventory at stage $N, \$ /$ unit/year. 
D Demand rate of finished product, units /year.

$\mathbf{I}_{\mathbf{h n}, \mathbf{p}} \quad$ Number of units of raw materials of type $h$, required for producing one unit of semi-finished Product in assigned plant p.

$\mathbf{I 1}_{\mathbf{j s v}, \mathbf{p}} \quad$ Number of units of raw materials of type $j$ (case 1), required for producing one unit of semi-finished Product in assigned plant $p$.

$\mathbf{I}_{\text {js,p }} \quad$ Number of units of raw materials of type $j$ (case 2), required for producing one unit of semi-finished Product in assigned plant $p$.

$\mathbf{I 3}_{\mathbf{j s}, \mathbf{p}} \quad$ Number of units of raw materials of type $j$ (case 3), required for producing one unit of semi-finished Product in assigned $p$.

$\mathbf{I}_{\mathbf{p}} \quad$ Number of units of semi-finished Product required for producing one unit of finished Product in assigned plant $p$

$\mathbf{A r}_{\mathbf{h n}, \mathbf{p}} \quad$ Setup (ordering) cost for raw material of type $h$ that is replenished from supplier $n$ to be manufactured in assigned plant $p$ in consolidation centre, $\$$ /order.

$\mathbf{A}_{\mathbf{h}, \mathbf{p}}$ Kanban delivering (empty/ full) containers of raw material of type $h$, at input buffer of assigned plant $p, \$$ /order.

$\mathbf{A}_{\mathbf{v}, \mathbf{p}} \quad$ Major set-up cost (ordering) cost for every group $v$ for raw material of type $j$ (case1), at input buffer of assigned plant $p, \$$ order.

$\mathbf{a}_{\text {jsv,p }} \quad$ Minor set-up (ordering) cost of item $j$ (case1) that is shipped in every group $v$ to input buffer of assigned plant $p$, \$lorder.

$\mathbf{A}_{\text {s,p }} \quad$ Major set-up cost (ordering) cost for every supplier $s$ for raw material of type $j$ (case 2), at input buffer of assigned plant $p, \$$ order.

$\mathbf{a}_{\mathbf{j}, \mathbf{p}} \quad$ Minor set-up (ordering) cost of item (case 2) that is shipped for every supplier sto input buffer of assigned plant $p, \$$ /order.

$\mathbf{A}_{\mathbf{j s}, \mathbf{p}} \quad$ Set-up cost (ordering) cost for every supplier $s$ for raw material of type $j$ (case 3 ), at input buffer of assigned plant $p$, \$/order

$\mathbf{A s}_{\mathbf{p}} \quad$ Setup (manufacturing) cost at assigned plant $p, \$ /$ batch.

$\mathbf{A s}_{\mathbf{f}} \quad$ Setup (manufacturing) cost at plant $N+1, \$ /$ batch.

$\mathbf{H r}_{\mathbf{h n}, \mathbf{p}}$ Holding cost of raw material of type $h$, in consolidation centre and at input buffer of assigned plant $p, \$ /$ unit/year.
$\mathbf{A D}_{\mathbf{p}} \quad$ Kanban delivering (empty/ full) containers of work-in-process (from/to) input buffer of plant $p, \$ /$ shipment.

$\mathbf{A D e}_{\mathbf{f}} \quad$ Kanban delivering cost of (empty/ full) containers at stage $N, \$ /$ shipment.

Time between successive of raw material of type $j$ (case1) shipments for the same group $v$, year

$\mathbf{t}_{\mathbf{p}}$

Time between successive shipments of semi-finished products at plant $p$, year.

$\mathbf{T u}_{\mathbf{p}} \quad$ Production time (uptime) in plant $p$, year.

T Cycle time, year.

$\mathbf{T C}_{\mathbf{m}} \quad$ Total cost of multi-stage supply chain system, \$/year.

$\mathbf{C r}_{1} \quad$ Cost of raw materials of type $h$ that enter consolidation centre, \$/year.

$\mathrm{Cr}_{\mathbf{h n}, \mathbf{P}}$

Cost of raw materials of type $h$, at input buffer of plant $p, \$$ year.

$\mathbf{C r}_{\mathbf{j}, \mathbf{P}}$

Cost of raw materials of type $j$, at input buffer of plant $p, \$$ year.

$\mathbf{C W}_{\text {ep }} \quad$ The cost of work-in-process exit plant $p$, \$/year.

CW $_{\text {ip }} \quad$ Cost of work-in-process that enter input buffer of plant $p, \$$ year.

$\mathbf{C}_{\mathbf{f}} \quad$ Cost of finished goods inventory, \$/year.

1 , if the raw material of type $h$ that is procured from supplier $n$ is assigned to plant $p$; 0 , otherwise.

1 , if the raw material of type $j$ (case 1 ) is procured from supplier sand delivered to assigned to plant $p$ in group $v ; 0$, otherwise.

$\omega_{\text {jsp }} \quad 1$, if the raw material of type $j$ (case 2) is procured from supplier sand delivered to assigned to plant $p ; 0$, otherwise. 
HSI $_{\text {jsv,p }}$ Holding cost of raw material of type $j$ (case 1 ) that is shipped in every group $v$ and held input buffer of assigned plant $p$, \$/unit/year.

\section{Variables:}

Quantity of finished products shipped per setup in period $\mathrm{T}$, units/batch.

$\mathbf{Q}_{\text {hn,p }} \quad$ Quantity of raw material (raw material of type $h$ that is procured from supplier $n$ ) per setup, units /batch.

$\mathbf{Q}_{\mathbf{0 h n}, \mathbf{p}}$ Quantity of raw material of type $h$ that is shipped to the input buffer each time, units /order.

$\mathbf{Q 1}_{\text {jsv,p }} \quad$ Quantity of raw material of type $j$ (case 1) that is procured from supplier $s$ ) per setup, units /batch.

$\mathbf{Q 1}_{\mathbf{0 j s v}, \mathbf{p}}$ Quantity of raw material of type j(case 1) that is procured from supplierand shipped to the input buffer in group $v$ each time, units /order.

Q2 js,p Quantity of raw material of type $j$ (case 2) that is procured from supplier sper setup, units /batch.

$\mathbf{Q 2}_{\mathbf{0 j s}, \mathbf{p}} \quad$ Quantity of raw material of type $j$ (case 2) that is procured from supplier $s$ and shipped to the input buffer in group $v$ each time, units /order.

$\mathbf{Q 3}_{\mathbf{j s}, \mathbf{p}} \quad$ Quantity of raw material of type $j$ (case 3 ) that is procured from supplier $s$ per setup, units /batch.

$\mathbf{Q 3}_{\mathbf{0 j s}, \mathbf{p}} \quad$ Quantity of raw material of type $j$ (case 3 ) that is procured from supplier $s$ and shipped to the input buffer in group $v$ each time, units /order.

$\mathbf{Q}_{\mathbf{p}} \quad$ Quantity of semi-finished product processed in plant $p$ per setup, units/batch.

$\mathbf{Q}_{\mathbf{p}}^{\backslash} \quad$ WIP shipping quantity that is ordered each time, units/order.

$\mathbf{Q}_{\mathrm{f}} \quad$ Finished goods shipping quantity, $\mathbf{Q}_{\text {avg,pi }}$ units/shipment.

$\mathbf{k}_{\mathbf{0 h}, \mathbf{p}} \quad$ Number of raw material shipments of type $h$ that are shipped to the input buffer of assigned plant $p$ from consolidation centre, order/batch.

$\mathbf{k}_{\mathbf{0 v}, \mathbf{p}} \quad$ Number of raw material shipments of type $j$ (case 1) that are shipped to the input buffer of plant $p$ in group $v$ from JIT delivery supplier $\mathrm{s}$, order/batch.

$\mathbf{k}_{\mathbf{0 j s}, \mathbf{p}} \quad$ Number of raw material shipments of type $j$ (case 2) that are shipped to the input buffer of plant $p$ from JIT delivery supplier $s$, order/batch. $\mathbf{\omega} \mathbf{2}_{\text {jsp }} \quad 1$, if the raw material of type $j$ (case 3 ) is procured from supplier sand delivered to assigned to plant $p ; 0$, otherwise.

Number of raw material shipments of type j (case 3 ) that are shipped to the input buffer of plant $p$ from every JIT delivery supplier $s$, order/batch.

$\mathbf{k}_{\mathbf{p}} \quad$ Number of shipments at stage $p$, order/batch.

$\mathbf{m}_{\mathbf{p}} \quad$ Number of shipments placed during production uptime at stage $p$, order/batch.

Number of shipments placed at plant $N+1$.

Number of shipments placed during uptime of plant $N+1$.

Inventory level at time t, units.

$\mathbf{Q}_{\text {avg,1i }}$

The average inventory held per cycle for raw material of type $h$ that is replenished from supplier $n$ at consolidation centre, units.

$\mathbf{Q}_{\text {avg,ih }}$

The average inventory held per cycle for raw material of type $h$, in the input buffer of plant $p$, units.

$\mathbf{Q}_{\text {avg,ijv }}$ The average inventory held per cycle for raw material of type $j$ (case 1), in the input buffer of plant $p$, units.

The average inventory held per cycle for raw material of type $j$ (case 2), in the input buffer of plant $p$, units.

$\mathbf{Q}_{\text {avg,ij }} \quad$ The average inventory held per cycle for raw material of type $j$ (case 3 ), in the input buffer of plant $p$, units.

The average inventory held per cycle for semi-finished parts in input buffer of plant $p$, units.

$\mathbf{Q}_{\text {avg,p }} \quad$ Average work-in-process, units.

$\mathbf{Q}_{\text {avg,f }} \quad$ Average finished goods inventory, units. 


\section{Cost of raw materials that enter the consolidation centre}

In the proposed model, raw materials of type $h$ are procured from outside longdistance supplier $n$. They are consumed at a given rate only during the production uptime of the assigned plant $p\left(T u_{p}\right)$. For this type a single ordering policy per cycle is used, where the raw material required for an inventory cycle for each plant $p$ are procured totally once before the beginning of production process in plant 1 according to the specific company's strategy and hold for a specific period until the beginning of production in plant1 in order to guarantee none delay. This type of material are divided up into multiple equal-size shipments deliveries, and shipped to the input buffer of assigned plant $p$ according to multi-ordering policy with equal number of small batches koh,p. The average inventory hold in consolidation centre during one period for the raw material that enters plant $p$ is:

$$
\mathrm{Q}_{\text {avg, }, 1 \mathrm{i}}=\left(\mathrm{Q}_{\mathrm{hn}, \mathrm{p}} / 2\right)\left(\mathrm{Tu}_{\mathrm{p}} / \mathrm{T}\right)+\mathrm{Q}_{\mathrm{hn,p}}\left(\sum_{\mathrm{r}=1}^{\mathrm{R}_{\mathrm{p}-1} \mathrm{t}_{\mathrm{r}} / \mathrm{T}}\right)
$$

The total cost associated with raw materials of type $\mathrm{h}$ that enter consolidation centre $C_{r l}$ is:

$$
\mathrm{Cr}_{1}=\left(\mathrm{D}_{\mathrm{hn}, \mathrm{p}} / \mathrm{Q}_{\mathrm{hn}, \mathrm{p}}\right) \mathrm{Ar}_{\mathrm{hn}, \mathrm{p}}+\left[\left(\mathrm{Q}_{\mathrm{hn}, \mathrm{p}} / 2\right)\left(\mathrm{Tu}_{\mathrm{p}} / \mathrm{T}\right)+\mathrm{Q}_{\mathrm{hn}, \mathrm{p}}\left(\sum_{\mathrm{r}=1}^{R_{\mathrm{p}-1}} \mathrm{t}_{\mathrm{r}} / \mathrm{T}\right)\right] \mathrm{Hr}_{\mathrm{hn}, \mathrm{p}}
$$

\section{Cost of raw material of type $h$ that enter input buffer-plant of plant $p$}

Raw materials of type $h$ are divided up into multiple equal-size shipment lots deliveries, and shipped to the input buffer of assigned plant $p$ according to multiordering policy with equal number of small batches koh,p. It is assumed that the demand rate of raw materials of type $h$ for the production process at the assigned plant $p$ is $I_{h n, p} P r_{p}$. $\operatorname{Pr}_{p}$ is the production rate of plant $p$. If the batch size of raw material of type $h$ that is shipped to the input buffer $Q_{h n, p}$ is divided into koh,p shipments with equal quantity $Q_{o h n, p}=Q_{h n, p} / k_{o h, p}$ at an equal interval $T u_{p} / k_{o h, p}$ then total number of orders $k_{o h, p}=Q_{h n, p} / Q_{o h n, p}$, the number of cycles over year is $D_{h n, p} / Q_{h n, p}$. By using a methodology similar to the work presented in ([30],[24] and [26]) but for this model there are multi item raw materials of type $h$ then the average inventory held in the input buffer per cycle for raw material of type $h$ that is replenished with multi-ordering policy is:

$$
\mathrm{Q}_{\text {avg, ih }}=\left(\mathrm{Q}_{0 h, \mathrm{p}} \mathrm{p} / 2\right)\left(\mathrm{Tu}_{\mathrm{p}} / \mathrm{T}\right)
$$

The total cost associated with raw materials of type $h$, at (input buffer-plant floor) of assigned plant $p, \mathrm{Cr}_{h n, p}$ is:

$$
\mathrm{Cr}_{\mathrm{hn}, \mathrm{p}}=\left(\mathrm{D}_{\mathrm{hn,p}} \mathrm{k}_{0 \mathrm{~h}, \mathrm{p}} / \mathrm{Q}_{\mathrm{hn,p}}\right) \mathrm{A}_{\mathrm{hn}, \mathrm{p}}+\left(\mathrm{Q}_{0 \mathrm{hn}, \mathrm{p}} / 2\right)\left(\mathrm{Tu}_{\mathrm{p}} / \mathrm{T}\right) \mathrm{Hr}_{\mathrm{hn}, \mathrm{p}}
$$

\section{Cost of raw material of type $\mathbf{j}$ that enter (input buffer-plant) of assigned plant $\mathbf{p}$}

Raw material of type $j$ (case1, case2, and case3) is procured from outside supplier $s$ in batches according to JIT delivery policy. The orders arrive in lots on time when an order is placed. In case1, raw materials that are required for assigned plant $p$ can be replenished at the same time using a common truck if suppliers are exist in the same region and the items can share the same truck. The suppliers that exist in same region are clustered in one group $v$ and share a common truck for the specific trip (which is also called milk-run transportation system). Every group (trip) $v$ contains set of items (Raw material of type $j$ that are procured from outside supplier $s$ ) that are shipped to the input buffer of assigned plant $p$ according to (multi-ordering policy, 
joint replenishment problem) with equal number of small batches $k_{0 v, p}$, the batch size of each item $Q 1_{0 j s v, p}$ differs. In case2, the suppliers may have different regions and more than one raw material is required from the supplier so these raw materials form a group and shipped to the input buffer of assigned plant $p$ according to (multiordering policy, joint replenishment problem) with equal number of small batches $k_{o v, p}$, the batch size of each item $Q 2_{0 j s, p}$ differs. In case3, the suppliers may have different regions and single raw material is required from every supplier so it is replenished separately with equal number of small batches $k_{0 j s, p}$, the batch size of each item Q30js,pdiffers.

For case1, it is assumed that the demand rate of raw materials of type $j$ for every group (trip) $v$ for the production process at the assigned plant $p$ is $I 1_{j s v, p} P r_{p}$. All raw materials of type $j$ are consumed at a given rate only during the production uptime $T u_{p}$ of the assigned plant $p$. If the batch size of raw material of type $j$ that is shipped to the input buffer of assigned plant $p$ in group $v, Q_{j s v, p}$ is divided into $k_{0 v, p}$ shipments with equal quantity $Q 1_{0 j s, p}=Q 1_{j s v, p} / k_{o v, p}$ at an equal interval $T u_{p} / k_{0 v, p}$ then total number of orders $k_{o v, p}=Q 1_{j s, p} / Q 1_{0 j s v, p}$, the number of cycles over year is $D 1_{j s v, p} / Q 1_{j s v, p}$. JIT delivery supplier delivers a shipment of raw materials of type $j$ with a major ordering cost $A_{v, p}$, regardless of the number of the materials included, and a minor ordering cost $a_{j s v, p}$, related to material, are incurred.

The basic cycle time associated with replenishing each group $v$ in the input buffer of assigned plant $p$ is $t_{v, p}$. This case resembles the case in [8] where Chen and Sarker assumed that the total numbers of deliveries from each vendor are equal with the case of un-capacitated model but for this research it is assumed that the total numbers of deliveries for each group are equal so the model in [8] can be adopted and $t_{v, p}$ equal to $t_{v, p=} T u_{p} / k_{o v, p}=Q 1_{j s v, p} / D 1_{j s v, p} k_{o v, p}$

For case2, it is assumed that the demand rate of raw materials of type $j$ that are received separately for the production process at the assigned plant $p$ is $12_{j s, p} P r_{p}$. If the batch size $Q 2_{j s, p}$ is ordered in $k_{0 j s, p}$ shipments with equal quantity $Q 2_{0 j s, p}=Q 2_{j s, p} /$ $k_{0 j s, p}$ at an equal interval $T u_{p} / k_{0 j s, p}$, then total number of orders $k_{0 j s, p}=Q 2_{j s, p} / Q 2_{0 j s, p}$, the number of cycles over year is $D 2_{j s, p} / Q 2_{j s, p}$.

For case 3 , it is assumed that the demand rate of raw materials of type $j$ that are received from the same suppliers and share the same truck for the production process at the assigned plant $p$ is $13_{j, s, p} \times \operatorname{Pr}$. If the batch size of raw material of type $j$ that is shipped to the input buffer of assigned plant $p, Q 3_{j, s, p}$. This quantity is divided into $k_{0 s, p}$ shipments with equal quantity $Q 3_{0 j s, p}=Q 3_{j s, p} / k_{0 s, p}$ at an equal interval $T u_{p} / k_{0 s, p}$, then total number of orders $k_{o s, p}=Q 3_{s, p} / Q 3_{0 j s, p}$, the number of cycles over year is $D 3_{j, s, p} / Q 3_{j s, p}$. JIT delivery supplier delivers a shipment of raw materials of type $j$ with a major ordering cost $A_{s, p}$, and a minor ordering cost $a_{j, p, p}$.

For case1, the average inventory $Q_{a v g, j i v}$ of raw materials that are held in the input buffer per cycle for raw material of type $j$ that is replenished in each group (trip) $v$ can be presented as:

$$
\mathrm{Q}_{\text {avg, } \mathrm{ijv}}=\left(\mathrm{Ql}_{0 \mathrm{jsv}, \mathrm{p}} / 2\right)\left(\mathrm{Tu}_{\mathrm{p}} / \mathrm{T}\right)
$$


Similarly for case2, the average inventory $Q_{a v g, i j s}$ of raw materials of type $j$ that are received separately and held in the input buffer of assigned plant $p$, per cycle is:

$$
\mathrm{Q}_{\mathrm{avg}, \mathrm{ijs}}=\left(\mathrm{Q} 2_{0 \mathrm{js}, \mathrm{p}} / 2\right)\left(\mathrm{Tu}_{\mathrm{p}} / \mathrm{T}\right)
$$

Similarly for case3, the average inventory $Q_{a v g, i j}$ of raw materials of type $j$ that are received from a supplier and hold in the input buffer of assigned plant $p$, per cycle is:

$$
\mathrm{Q}_{\mathrm{avg}, \mathrm{ij}}=\left(\mathrm{Q} 3_{0 \mathrm{js}, \mathrm{p}} / 2\right)\left(\mathrm{Tu}_{\mathrm{p}} / \mathrm{T}\right)
$$

The total cost associated with raw materials of type $j$ that enter (input buffer-plant floor) of plant $p, C r_{j, p}$ is:

$$
\begin{aligned}
& \mathrm{Cr}_{\mathrm{j}, \mathrm{p}}=\left(\mathrm{D} 1_{\mathrm{jsv}, \mathrm{p}} \mathrm{k}_{0 \mathrm{v}} / \mathrm{Q} 1_{\mathrm{jsv}, \mathrm{p}}\right)\left(\mathrm{A}_{\mathrm{v}, \mathrm{p}}+\mathrm{a}_{\mathrm{jsv}, \mathrm{p}}\right)+\left(\mathrm{Q} 1_{0 \mathrm{jsv}, \mathrm{p}} / 2\right)\left(\mathrm{Tu}_{\mathrm{p}} / \mathrm{T}\right) \mathrm{HSI}_{\mathrm{jsv}, \mathrm{p}}+\left(\mathrm{D} 2_{\mathrm{js}, \mathrm{p}} \mathrm{k}_{0 \mathrm{~s}, \mathrm{p}} / \mathrm{Q} 2_{\mathrm{js}, \mathrm{p}}\right)\left(\mathrm{A}_{\mathrm{s}, \mathrm{p}}+\mathrm{a}_{\mathrm{js}, \mathrm{p}}\right) \\
& \left(\mathrm{Q} 2_{0 \mathrm{js}, \mathrm{p}} / 2\right)\left(\mathrm{Tu}_{\mathrm{p}} / \mathrm{T}\right) \mathrm{HS} 1_{\mathrm{js,p}}+\left(\mathrm{D} 3_{\mathrm{js}, \mathrm{p}} \mathrm{k}_{0 \mathrm{js}} / \mathrm{Q} 3_{\mathrm{js}, \mathrm{p}}\right) \mathrm{A}_{\mathrm{js,p}}+\left(\mathrm{Q} 3_{0 \mathrm{js}, \mathrm{p}} / 2\right)\left(\mathrm{Tu}_{\mathrm{p}} / \mathrm{T}\right) \mathrm{HSI} 2_{\mathrm{js}, \mathrm{p}}
\end{aligned}
$$

\section{Cost of work-in-process exit plant $p$}

Raw material of type $h$ and $j$ are manufactured to semi-finished parts during the uptime period of the plant $p$, in order to match the demand during cycle time T. The production at plant $p$ stops when the quantity of parts produced is enough for the demand at plant $p+1$. The demand of $Q_{p}^{\prime}$ of semi-finished products at the end of every $t_{p}$ time units forces inventory to build-up in a saw-tooth fashion, $Q_{p}$ units of semi-finished parts are instantaneously consumed to satisfy demand of $Q_{p}^{\prime}$ units at each $t_{p}$ time units. During the uptime $m_{p}$ batches are built before they are shipped. The number of kanbans deliveries is equivalent to the number of shipments since every shipment is accompanied by kanban. The average inventory of WIP also can be calculated with similar methodology as used in Wang and Sarker[20] using Eq.(9).

$$
\mathrm{Q}_{\text {avg, }, \mathrm{p}}=\frac{1}{2} \mathrm{Q}_{\mathrm{p}}^{\backslash}\left(\mathrm{k}_{\mathrm{p}}-\mathrm{m}_{\mathrm{p}}+1\right)
$$

Where $k_{p}$ is the number of shipments of WIP and $m_{p}$ is the number of shipments placed during the uptime. The total cost associated with WIP that exit plant $p, C W_{e p}$ is:

$$
\mathrm{CW}_{\mathrm{ep}}=\mathrm{As}_{\mathrm{p}}\left(\mathrm{D}_{\mathrm{p}} / \mathrm{Q}_{\mathrm{p}}\right)+\frac{1}{2} \mathrm{Q}_{\mathrm{p}}^{\backslash}\left(\mathrm{k}_{\mathrm{p}}-\mathrm{m}_{\mathrm{p}}+1\right) \mathrm{Hs}_{\mathrm{p}}
$$

\section{Cost of WIP that enter input buffer of plant $p(p=2,3, \ldots \ldots . . . N+1)$}

The production rate at plant $p$ is carried at $\operatorname{Pr}_{p}$, demand rate of the semi-finished product for production process at plant $p$ is $I_{p-1} P r_{p}$. The production at plant $p$ is equal to the required quantity of semi-finished goods. When the containers of semi-finished products in the input buffer of plant $p$ are consumed, the empty containers are taken to the output buffer of plant $p-1$ where full containers with lot size $Q_{(p-1)}^{\prime}$ of semifinished parts are located. Then they are replaced with full containers and they are shipped to the input buffer of plant $p$ and held until consumed. The average inventory held per cycle for semi-finished products is

$$
\mathrm{Q}_{\mathrm{avg}, \mathrm{pi}}=\left(\mathrm{Q}_{\mathrm{p}-1}^{\backslash} / 2\right)\left(\mathrm{Tu}_{\mathrm{p}} / \mathrm{T}\right)
$$

The total cost associated with WIP that enter input buffer of plant $p, C W_{i p}$ is: 
$\mathrm{CW}_{\mathrm{ip}}=\left(\mathrm{D}_{\mathrm{p}-1} / \mathrm{Q}_{\mathrm{p}-1}^{\backslash}\right) \mathrm{AD}_{\mathrm{p}}+\left(\mathrm{Q}_{\mathrm{p}-1}^{\backslash} / 2\right)\left(\mathrm{Tu}_{\mathrm{p}} / \mathrm{T}\right) \mathrm{Hs}_{\mathrm{p}-1}$

\section{Cost of finished goods inventory}

The output of plant $N+1$ forms the inventory model for the finished goods. The total stock in plant $(N+1)$ increases at rate of $P r_{f}$. The finished goods are shipped to the warehouse then to customers. Due to constant character of demand rate, the optimal quantity of finished goods inventory has fixed batch size and each shipment is made at a fixed interval. The production at plant $N+1$ stops when the quantity of finished goods produced is enough to meet the demand of customers, and as in the case of WIP, the shipment of stocks continues until the demand is satisfied. The behaviour of finished goods inventory is the same as the WIP inventory. So the average finished goods inventory can be calculated as:

$\mathrm{Q}_{\mathrm{avg}, \mathrm{f}}=\frac{1}{2} \mathrm{Q}_{\mathrm{f}}\left(\mathrm{k}_{\mathrm{f}}-\mathrm{m}_{\mathrm{f}}+1\right)$

The total cost associated with finished goods inventory is $C_{f}$ :

$\mathrm{C}_{\mathrm{f}}=(\mathrm{D} / \mathrm{Q}) \mathrm{As}_{\mathrm{f}}+\frac{1}{2} \mathrm{Q}_{\mathrm{f}}\left(\mathrm{k}_{\mathrm{f}}-\mathrm{m}_{\mathrm{f}}+1\right) \mathrm{Hs}_{\mathrm{f}}+\left(\mathrm{D} / \mathrm{Q}_{\mathrm{f}}\right) \mathrm{ADe}_{\mathrm{f}}$

\section{Total cost of multi-stage supply chain}

To obtain general expression for the total cost function, $\mathrm{TC}_{\mathrm{m}}$ of the whole supply chain syetem, equations (2), (4), (8), (10), (12) and (14) are combined to form this cost function as shown by Eq. (15).

$$
\begin{aligned}
& \mathrm{TC}_{\mathrm{m}}=\mathrm{Cr}_{1}+\mathrm{Cr}_{\mathrm{hn}, \mathrm{p}}+\mathrm{Cr}_{\mathrm{j}, \mathrm{p}}+\mathrm{CW}_{\mathrm{ep}}+\mathrm{CW}_{\mathrm{ip}}+\mathrm{C}_{\mathrm{f}} \\
& =\sum_{\mathrm{p}=1}^{\mathrm{N}+1} \sum_{\mathrm{n}=1}^{\mathrm{NN}} \sum_{\mathrm{h}=1}^{\mathrm{H}}\left[\gamma_{\mathrm{hnp}}\left(\left(\frac{\mathrm{D}_{\mathrm{hn}, \mathrm{p}}}{\mathrm{Q}_{\mathrm{hn}, \mathrm{p}}}\right) \mathrm{Ar}_{\mathrm{hn}, \mathrm{p}}+\left(\frac{\mathrm{Q}_{\mathrm{hn}, \mathrm{p}}}{2}\right)\left(\frac{\mathrm{Tu}_{\mathrm{p}}}{\mathrm{T}}\right) \mathrm{Hr}_{\mathrm{hn}, \mathrm{p}}+\left(\frac{\mathrm{D}_{\mathrm{hn}, \mathrm{p}} \mathrm{k}_{0 \mathrm{~h}, \mathrm{p}}}{\mathrm{Q}_{\mathrm{hn}, \mathrm{p}}}\right) \mathrm{A}_{\mathrm{hn}, \mathrm{p}}+\left(\frac{\mathrm{Q}_{0 \mathrm{hn}, \mathrm{p}}}{2}\right)\left(\frac{\mathrm{Tu}_{\mathrm{p}}}{\mathrm{T}}\right) \mathrm{Hr}_{\mathrm{hn}, \mathrm{p}}\right)\right] \\
& +\sum_{\mathrm{p}=2}^{\mathrm{N}+1} \sum_{\mathrm{n}=1}^{\mathrm{NN}} \sum_{\mathrm{h}=1}^{\mathrm{H}}\left[\gamma_{\mathrm{hnp}} \mathrm{Q}_{\mathrm{hn}, \mathrm{p}}\left(\frac{\sum_{\mathrm{r}=1}^{\mathrm{R}_{\mathrm{p}-1}} \mathrm{t}_{\mathrm{r}}}{\mathrm{T}}\right) \mathrm{Hr}_{\mathrm{hn}, \mathrm{p}}\right]+\sum_{\mathrm{p}=1}^{\mathrm{N}+1} \sum_{\mathrm{v}=1}^{\mathrm{v}} \sum_{\mathrm{s}=1}^{\mathrm{S}} \sum_{\mathrm{j}}^{\mathrm{J}}\left[\varphi _ { \mathrm { jsvp } } \left(\left(\frac{\mathrm{D}_{\mathrm{jsv}, \mathrm{p}} \mathrm{k}_{0 \mathrm{v}}}{\mathrm{Q}_{\mathrm{jsv}, \mathrm{p}}}\left(\mathrm{A}_{\mathrm{v}, \mathrm{p}}+\mathrm{a}_{\mathrm{jsv}, \mathrm{p}}\right)\right)\right.\right. \\
& \left.\left.+\left(\frac{\mathrm{Q}_{0 \mathrm{jsv}, \mathrm{p}}}{2}\right)\left(\frac{\mathrm{Tu}_{\mathrm{p}}}{\mathrm{T}}\right) \mathrm{HSI} \mathrm{j}_{\mathrm{jsv}, \mathrm{p}}\right)\right]+\sum_{\mathrm{p}=1}^{\mathrm{N}+1} \sum_{\mathrm{s}=1}^{\mathrm{S}} \sum_{\mathrm{j}=1}^{\mathrm{J}}\left[\omega _ { \mathrm { jsp } } \left(\left(\frac{\mathrm{D}_{\mathrm{js,p}} \mathrm{k}_{0 \mathrm{~s}}}{\mathrm{Q}_{\mathrm{js}, \mathrm{p}}}\left(\mathrm{A}_{\mathrm{s}, \mathrm{p}}+\mathrm{a}_{\mathrm{js,p}}\right)+\left(\frac{\mathrm{Q} 2_{0 \mathrm{js}, \mathrm{p}}}{2}\right)\left(\frac{\mathrm{Tu}_{\mathrm{p}}}{\mathrm{T}}\right) \mathrm{HSI1} 1_{\mathrm{js,p}}\right)\right.\right. \\
& \left.\left.+\frac{D_{j s, p} k_{0 j s, p}}{Q_{j s, p}}\left(A_{j s, p}\right)+\left(\frac{Q_{0 j s, p}}{2}\right)\left(\frac{T u_{p}}{T}\right) H S I 2_{j s, p}\right)\right]+\sum_{p=1}^{N}\left[\operatorname{As}_{p} \frac{D_{p}}{Q_{p}}+\frac{1}{2} Q_{p}^{\searrow}\left(k_{p}-m_{p}+1\right) H s_{p}\right] \\
& +\sum_{\mathrm{p}=2}^{\mathrm{N}+1}\left[\left(\frac{\mathrm{D}_{\mathrm{p}-1}}{\mathrm{Q}_{\mathrm{p}-1}^{\prime}}\right) \mathrm{AD}_{\mathrm{p}}+\left(\frac{\mathrm{Q}_{\mathrm{p}-1}^{\backslash}}{2}\right)\left(\frac{\mathrm{Tu}_{\mathrm{p}}}{\mathrm{T}}\right) \mathrm{Hs}_{\mathrm{p}-1}\right]+\left(\frac{\mathrm{D}}{\mathrm{Q}}\right) \mathrm{As}_{\mathrm{f}}+\frac{1}{2} \mathrm{Q}_{\mathrm{f}}\left(\mathrm{k}_{\mathrm{f}}-\mathrm{m}_{\mathrm{f}}+1\right) \mathrm{Hs}_{\mathrm{f}}+\left(\frac{\mathrm{D}}{\mathrm{Q}_{\mathrm{f}}}\right) \mathrm{ADe}_{\mathrm{f}}
\end{aligned}
$$

By substituting by the following relations in Eq. (16) one can obtain a generalized cost function as represented by Eq. (17):

$$
\begin{aligned}
& \mathbf{Q}_{\mathbf{0 h n , p}}=\frac{\mathrm{Q}_{\mathrm{hn}, \mathrm{p}}}{\mathrm{k}_{0 \mathrm{~h}, \mathrm{p}}} ; \mathbf{Q} \mathbf{1}_{0 \mathrm{jsv}, \mathbf{p}}=\frac{\mathrm{Q}_{\mathrm{jsv}, \mathrm{p}}}{\mathrm{k}_{0 \mathrm{v}, \mathrm{p}}} ; \mathbf{Q} \mathbf{2}_{0 \mathrm{jsv}, \mathbf{p}}=\frac{\mathrm{Q} 2_{\mathrm{js}, \mathrm{p}}}{\mathrm{k}_{0 \mathrm{~s}, \mathrm{p}}} ; \mathbf{Q} \mathbf{3}_{\mathbf{0 j s v}, \mathbf{p}}=\frac{\mathrm{Q} 3_{\mathrm{js}, \mathrm{p}}}{\mathrm{k}_{0 \mathrm{js}}} ; \mathbf{Q}_{\mathbf{p}}^{\prime}=\frac{\mathrm{Q}_{\mathrm{p}}}{\mathrm{k}_{\mathrm{p}}} ; \mathbf{Q}_{\mathbf{f}}=\frac{\mathrm{Q}}{\mathrm{k}_{\mathrm{f}}} ; \\
& \frac{\mathbf{T u}_{\mathbf{p}}}{\mathbf{T}}=\frac{\mathrm{D}_{\mathrm{p}}}{\mathrm{Pr}_{\mathrm{p}}} ; \frac{\mathbf{T u}_{\mathrm{N}+1}}{\mathbf{T}}=\frac{\mathrm{D}}{\mathrm{Pr}_{\mathrm{f}}} ; \mathbf{t}_{\mathbf{r}}=\mathrm{t}_{\mathrm{p}}=\frac{\mathrm{T}}{\mathrm{k}_{\mathrm{p}}}=\frac{\mathrm{T}}{\mathrm{k}_{\mathrm{r}}} ; \frac{\mathbf{D}_{\mathrm{hn}, \mathbf{p}}}{\mathbf{Q}_{\mathrm{hn}, \mathbf{p}}}=\frac{\mathrm{D}_{\mathrm{jsv}, \mathrm{p}}}{\mathrm{Q}_{\mathrm{jsv}, \mathrm{p}}}=\frac{\mathrm{D}_{\mathrm{js}, \mathrm{p}}}{\mathrm{Q}_{\mathrm{js}, \mathrm{p}}}=\frac{\mathrm{D}_{\mathrm{p}}}{\mathrm{Q}_{\mathrm{p}}}=\frac{\mathrm{D}}{\mathrm{Q}}=\frac{\mathrm{D}_{\mathrm{p}-1}}{\mathrm{Q}_{\mathrm{p}-1}} ;
\end{aligned}
$$




$$
\begin{aligned}
& \mathbf{Q}_{\mathbf{p}}=\mathrm{I}_{\mathrm{p}} \mathrm{Q}_{\mathrm{p}+1} ; \mathbf{Q}_{\mathbf{p}}=\mathrm{I}_{\mathrm{p}} \cdot \mathrm{I}_{\mathrm{P}+1} \ldots \ldots . \mathrm{I}_{\mathrm{N}} \mathrm{Q}_{\mathrm{N}+1} ; \mathbf{Q}_{\mathbf{p}}=\mathrm{I}_{\mathrm{p}} \cdot \mathrm{I}_{\mathrm{P}+1} \ldots \ldots . \mathrm{I}_{\mathrm{N}} \mathrm{Q}_{\mathrm{N}+1} ; \mathbf{Q}_{\mathrm{N}+\mathbf{1}}=\mathrm{Q} \\
& \mathbf{Q}_{\mathbf{p}}=\left(\prod_{\mathrm{y}=1}^{\mathrm{N}} \mathrm{I}_{\mathrm{y}}\right) \mathrm{Q} ; \mathbf{L}_{\mathbf{p}}=\mathrm{I}_{\mathrm{p}} \cdot \mathrm{I}_{\mathrm{P}+1} \ldots \ldots . . \mathrm{I}_{\mathrm{N}} ; \mathbf{D}_{\mathbf{P}}=\mathrm{L}_{\mathrm{p}} . \mathrm{D} \text {; } \\
& \mathbf{Q}_{\text {hn,p }}=\mathrm{I}_{\mathrm{h}, \mathrm{p}} \cdot \mathrm{I}_{\mathrm{p}} \mathrm{I}_{\mathrm{p}+1} \ldots \ldots \ldots \ldots \mathrm{I}_{\mathrm{N}} \mathrm{Q}=\mathrm{I}_{\mathrm{hn}, \mathrm{p}} \cdot \mathrm{L}_{\mathrm{p}} \cdot \mathrm{Q} ; \quad \mathbf{Q} \mathbf{1}_{\mathbf{j s v}, \mathbf{p}}=\mathrm{Il}_{\mathrm{jsv}, \mathrm{p}} \cdot \mathrm{I}_{\mathrm{p}} \cdot \mathrm{I}_{\mathrm{p}+1} \ldots \ldots \ldots \ldots \mathrm{I}_{\mathrm{N}} \mathrm{Q}=\mathrm{I} 1_{\text {jsv,p }} \cdot \mathrm{L}_{\mathrm{p}} \cdot \mathrm{Q} \\
& \mathbf{Q 2} \mathbf{2}_{\mathbf{j s}, \mathbf{p}}=\mathrm{I} 2_{\mathrm{js}, \mathrm{p}} \cdot \mathrm{I}_{\mathrm{p}} \cdot \mathrm{I}_{\mathrm{p}+1} \ldots \ldots \ldots \ldots \mathrm{I}_{\mathrm{N}} \mathrm{Q}=\mathrm{I} 2_{\mathrm{js}, \mathrm{p}} \cdot \mathrm{L}_{\mathrm{p}} \cdot \mathrm{Q} ; \mathbf{Q} \mathbf{3}_{\mathrm{js}, \mathbf{p}}=\mathrm{I} 3_{\mathrm{js}, \mathrm{p}} \cdot \mathrm{I}_{\mathrm{p}} \cdot \mathrm{I}_{\mathrm{p}+1} \ldots \ldots \ldots \ldots \mathrm{I}_{\mathrm{N}} \mathrm{Q}=\mathrm{I} 3_{\mathrm{js}, \mathrm{p}} \cdot \mathrm{L}_{\mathrm{p}} \cdot \mathrm{Q} \\
& \mathbf{m}_{\mathbf{p}}=\frac{\mathrm{k}_{\mathrm{p}} \mathrm{L}_{\mathrm{p}} \mathrm{D}_{\mathrm{p}}}{\operatorname{Pr}_{\mathrm{p}}} ; \mathbf{m}_{\mathbf{f}}=\frac{\mathrm{k}_{\mathrm{f}} \mathrm{D}}{\operatorname{Pr}_{\mathrm{f}}} ; \\
& \mathbf{T C}_{\mathrm{m}}=\frac{\mathrm{D}}{\mathrm{Q}}\left\{\sum_{\mathrm{p}=1}^{\mathrm{N}+1} \sum_{\mathrm{n}=1}^{\mathrm{NN}} \sum_{\mathrm{h}=1}^{\mathrm{H}}\left[\gamma_{\mathrm{hnp}} \mathbf{k}_{0 \mathrm{~h}, \mathrm{p}} \mathbf{A}_{\mathrm{hn}, \mathrm{p}}\right]+\sum_{\mathrm{p}=1}^{\mathrm{N}+1} \sum_{\mathrm{v}=1}^{\mathrm{V}} \sum_{\mathrm{s}=1}^{\mathrm{S}} \sum_{\mathrm{j}}^{\mathrm{J}}\left[\boldsymbol{\varphi}_{\mathrm{jsvp}} \mathbf{k}_{0 \mathrm{v}, \mathrm{p}}\left(\mathbf{A}_{\mathrm{v}, \mathrm{p}}+\mathbf{a}_{\mathrm{jsv}, \mathrm{p}}\right)\right]+\right. \\
& \sum_{p=1}^{N+1} \sum_{s=1}^{S} \sum_{j=1}^{J}\left[\omega_{j s p}\left(k_{0 s, p}\left(A_{s, p}+a_{j s, p}\right)+\omega 1_{j s p} k_{0 j s, p}\left(A_{j s, p}\right)\right)\right]+\sum_{p=1}^{N}\left[k_{p} A D_{p+1}\right]+k_{f} A_{D d} \\
& \left.+\sum_{p=1}^{N+1} \sum_{n=1}^{N N} \sum_{h=1}^{H}\left[\gamma_{h n p} A r_{h n, p}\right]+\sum_{p=1}^{N}\left[A s_{p}\right]+A s_{f}\right\}+\frac{Q}{2}\left\{\sum_{p=1}^{N+1} \sum_{n=1}^{N N} \sum_{h=1}^{H}\left[\gamma_{h n p}\left(\frac{I_{h n, p} \cdot \mathbf{L}_{p}^{2} \cdot D}{k_{0 h, p} P_{p}}\right) H r_{h n, p}\right]\right.
\end{aligned}
$$

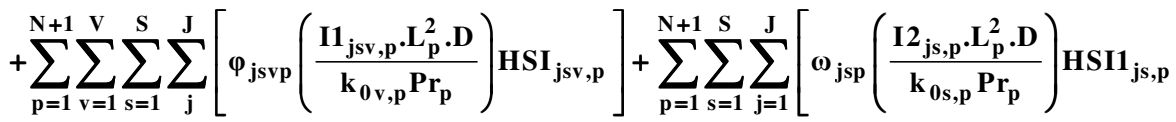

$$
\begin{aligned}
& \left.+\omega 1_{j s p}\left(\frac{I 3_{j s, p} \cdot L_{p}^{2} \cdot D}{k_{0 j s, p} P_{p}}\right) H S I 2_{j s, p}\right]+\sum_{p=1}^{N}\left[\left(\frac{1}{k_{p}}\right) H s_{p}\left(L_{p}+\left(\frac{I_{p} \cdot L_{p+1}^{2} \cdot D}{P r_{p+1}}\right)\right)\right]+ \\
& \sum_{\mathrm{p}=2}^{\mathrm{N}+1} \sum_{\mathrm{n}=1}^{\mathrm{NN}} \sum_{\mathrm{h}=1}^{\mathrm{H}}\left[2 \cdot \gamma_{\mathrm{hnp}} \cdot \mathrm{I}_{\mathrm{hn}, \mathrm{p}} \cdot \mathrm{L}_{\mathrm{p}} \cdot \mathrm{Hr}_{\mathrm{hn}, \mathrm{p}}\left(\sum_{\mathrm{r}=1}^{\mathrm{R}_{\mathrm{p}-1}}\left(1 / \mathrm{k}_{\mathrm{r}}\right)\right)\right]+\left(\frac{1}{\mathrm{k}_{\mathrm{f}}}\right) \mathrm{Hs}_{\mathrm{f}}+ \\
& \left.\sum_{p=1}^{N+1} \sum_{n=1}^{N N} \sum_{h=1}^{H}\left[\gamma_{h n p}\left(\frac{I_{h n, p} \cdot L_{p}^{2} \cdot D}{\operatorname{Pr}_{p}}\right) H r_{h n, p}\right]+\sum_{p=1}^{N}\left[L_{p} \cdot H s_{p}\left(1-\frac{L_{p} D}{\operatorname{Pr}_{p}}\right)\right]+H s_{f}\left(1-\left(\frac{D}{P_{r_{f}}}\right)\right)\right\}
\end{aligned}
$$

\section{SOLUTION METHODOLOGY}

The current paper proposes to solve this problem optimally using Branch and bound. The optimization mathematical model of the problem can be represented by the following. The model seeks to find the optimal minimum cost with respecting the non negativity and integer constraints of the variables.

Minimize $\mathbf{T C}_{\mathbf{m}}\left(\mathbf{k}_{\mathbf{0 h}, \mathbf{p}}, \mathbf{k}_{\mathbf{0 v}, \mathbf{p}}, \mathbf{k}_{\mathbf{0 s , p}}, \mathbf{k}_{\mathbf{0 j s}, \mathbf{p}}, \mathbf{k}_{\mathbf{P}}, \mathbf{k}_{\mathbf{f}}, \mathbf{Q}\right)$

Subject to

$\mathbf{k}_{\mathbf{0 h}, \mathbf{p}}, \mathbf{k}_{\mathbf{0 v}, \mathbf{p}}, \mathbf{k}_{\mathbf{0 s , \mathbf { p }}}, \mathbf{k}_{\mathbf{0 j s}, \mathbf{p}}, \mathbf{k}_{\mathbf{p}}, \mathbf{k}_{\mathbf{f}}, \mathbf{Q} \geq \mathbf{1}$ and all are integers

But in order to solve this model optimally using B\&B one should have an efficient lower bound in order to minimize the solution time and the search space. By the following the lower bound for this model will be presented. By relaxing the previous nonlinear integer programming model, the optimal total cost of a multi-stage supply chain system can be obtained as: 


$$
\begin{aligned}
& \mathbf{T C}_{\mathbf{m}}\left(\mathbf{k}_{\mathbf{0 h}, \mathbf{p}}{ }^{*}, \mathbf{k}_{\mathbf{0 v}, \mathbf{p}}{ }^{*}, \mathbf{k}_{\mathbf{0 s , \mathbf { p }}}{ }^{*}, \mathbf{k}_{\mathbf{0 j \mathrm { s }}}{ }^{*}, \mathbf{k}_{\mathbf{p}}{ }^{*}, \mathbf{k}_{\mathbf{f}}{ }^{*}, \mathbf{Q}^{*}\right)=\sqrt{2 \mathrm{D}}\left\{\sum_{p=1}^{N+1} \sum_{n=1}^{N N} \sum_{h=1}^{H}(\sqrt{2 \mathrm{AI}})+\sum_{p=1}^{N+1} \sum_{v=1}^{V} \sum_{s=1}^{S} \sum_{j}^{J}[\sqrt{2 \mathrm{BL}}]\right. \\
& \left.+\sum_{p=1}^{N+1} \sum_{s=1}^{S} \sum_{j=1}^{J}[(\sqrt{2 \mathrm{CM}})+(\sqrt{2 \mathrm{EU}})]+\sum_{\mathbf{p}=1}^{\mathrm{N}}(\sqrt{2 \mathrm{FV}})+\sqrt{2 \mathrm{GX}}+\sqrt{\alpha \mathbf{\beta}}\right\}
\end{aligned}
$$

\section{Proof.}

By replacing $T C_{m}$ with $Z$ and substituting the values of $A, B, C, E, F, G, I, L, M, U, V$, $X, \alpha, \beta$ in Eq. (17) where:

$$
\begin{aligned}
& \mathbf{A}=\gamma_{\text {hnp }} \mathrm{A}_{\mathrm{hn}, \mathrm{p}} ; \quad \mathbf{B}=\varphi_{\mathrm{jsvp}}\left(\mathrm{A}_{\mathrm{v}, \mathrm{p}}+\mathrm{a}_{\mathrm{jsv}, \mathrm{p}}\right) ; \quad \mathbf{C}=\omega_{\mathrm{jsp}}\left(\mathrm{A}_{\mathrm{s}, \mathrm{p}}+\mathrm{a}_{\mathrm{js}, \mathrm{p}}\right) ; \quad \mathbf{E}=\left(\mathrm{A}_{\mathrm{js}, \mathrm{p}}\right) ; \mathbf{F}=\mathrm{AD}_{\mathrm{p}+1} \\
& \mathbf{G}=\mathrm{ADe}_{\mathrm{f}} ; \boldsymbol{\alpha}=\sum_{\mathrm{p}=1}^{\mathrm{N}+1 \mathrm{NN}} \sum_{\mathrm{n}=1}^{\mathrm{N}} \sum_{\mathrm{h}=1}^{\mathrm{H}}\left[\gamma_{\mathrm{hnp}} \mathrm{Ar}_{\mathrm{hn}, \mathrm{p}}\right]+\sum_{\mathrm{p}=1}^{\mathrm{N}}\left[\mathrm{As}_{\mathrm{p}}\right]+\mathrm{As}_{\mathrm{f}} ; \quad \mathbf{I}=\gamma_{\mathrm{hnp}}\left(\frac{\mathrm{I}_{\mathrm{hn}, \mathrm{p}} \cdot \mathrm{L}_{\mathrm{p}}^{2} \mathrm{D}}{\mathrm{Pr}_{\mathrm{p}}}\right) \mathrm{Hr}_{\mathrm{hn}, \mathrm{p}} \\
& \mathbf{L}=\varphi_{\mathrm{jsvp}}\left(\frac{\mathrm{I} 1_{\mathrm{jsv}, \mathrm{p}} \cdot \mathrm{L}_{\mathrm{p}}^{2} \cdot \mathrm{Q} . \mathrm{D}}{\mathrm{Pr}_{\mathrm{p}}}\right) \mathrm{HSI}_{\mathrm{jsv}, \mathrm{p}} ; \mathbf{M}=\omega_{\mathrm{jsp}}\left(\frac{\mathrm{I} 2_{\mathrm{js}, \mathrm{p}} \cdot \mathrm{L}_{\mathrm{p}}^{2} \cdot \mathrm{D}}{\mathrm{Pr}_{\mathrm{p}}}\right) \mathrm{HSI} 1_{\mathrm{js}, \mathrm{p}} ; \quad \mathbf{U}=\left(\frac{\mathrm{I} 3_{\mathrm{js}, \mathrm{p}} \cdot \mathrm{L}_{\mathrm{p}}^{2} \cdot \mathrm{D}}{\mathrm{Pr}_{\mathrm{p}}}\right) \mathrm{HSI} 2_{\mathrm{js}, \mathrm{p}} \\
& \mathbf{V}=\left[\mathrm{Hs}_{\mathrm{p}}\left(\mathrm{L}_{\mathrm{p}}+\left(\frac{\mathrm{I}_{\mathrm{p}} \mathrm{L}_{\mathrm{p}+1}^{2} \cdot \mathrm{D}}{\mathrm{Pr}_{\mathrm{p}+1}}\right)\right)+\sum_{\mathrm{p}=2}^{\mathrm{N}+1} \sum_{\mathrm{n}=1}^{\mathrm{NN}} \sum_{\mathrm{h}=1}^{\mathrm{H}}\left[2 \cdot \gamma_{\mathrm{hnp}} \cdot \mathrm{I}_{\mathrm{hn}, \mathrm{p}} \cdot \mathrm{L}_{\mathrm{p}} \cdot \mathrm{Hr}_{\mathrm{hn}, \mathrm{p}}\left(\sum_{\mathrm{r}=1}^{\mathrm{R}_{\mathrm{p}-1}}\left(1 / \mathrm{k}_{\mathrm{r}}\right)\right)\right]\right] \\
& \mathbf{X}=\left(\mathrm{Hs}_{\mathrm{f}}\right) ; \boldsymbol{\beta}=\sum_{\mathrm{p}=1}^{\mathrm{N}+1} \sum_{\mathrm{n}=1}^{\mathrm{NN}} \sum_{\mathrm{h}=1}^{\mathrm{H}}\left[\gamma_{\mathrm{hnp}}\left(\frac{\mathrm{I}_{\mathrm{hn}, \mathrm{p}} \cdot \mathrm{L}_{\mathrm{p}}^{2} \cdot \mathrm{D}}{\operatorname{Pr}_{\mathrm{p}}}\right) \mathrm{Hr}_{\mathrm{hn}, \mathrm{p}}\right]+\sum_{\mathrm{p}=1}^{\mathrm{N}}\left[\mathrm{L}_{\mathrm{p}} \cdot \mathrm{Hs}_{\mathrm{p}}\left(1-\frac{\mathrm{L}_{\mathrm{p}} \mathrm{D}}{\operatorname{Pr}_{\mathrm{p}}}\right)\right]+\mathrm{Hs}_{\mathrm{f}}\left(1-\left(\frac{\mathrm{D}}{\operatorname{Pr}_{\mathrm{f}}}\right)\right)
\end{aligned}
$$

Then Eq. (18) can be rewritten as

$$
\begin{aligned}
& \mathrm{Z}\left(\mathrm{k}_{0 \mathrm{~h}, \mathrm{p}}, \mathrm{k}_{0 \mathrm{v}, \mathrm{p}}, \mathrm{k}_{0 \mathrm{~s}, \mathrm{p}}, \mathrm{k}_{0 \mathrm{js}, \mathrm{p}}, \mathrm{K}_{\mathrm{p}}, \mathrm{K}_{\mathrm{f}}, \mathrm{Q}\right)=\frac{\mathrm{D}}{\mathrm{Q}}\left\{\sum_{\mathrm{p}=1}^{\mathrm{N}+1 \mathrm{~N}} \sum_{\mathrm{n}=1}^{\mathrm{N}} \sum_{\mathrm{h}=1}^{\mathrm{H}}\left[\mathrm{k}_{0 \mathrm{~h}, \mathrm{p}} \mathrm{A}\right]+\sum_{\mathrm{p}=1}^{\mathrm{N}+1} \sum_{\mathrm{v}=1}^{\mathrm{V}} \sum_{\mathrm{s}=1}^{\mathrm{S}} \sum_{\mathrm{j}}^{\mathrm{J}}\left[\mathrm{k}_{0 \mathrm{v}, \mathrm{p}} \mathrm{B}\right]+\right. \\
& \left.\sum_{\mathrm{p}=1}^{\mathrm{N}+1} \sum_{\mathrm{s}=1}^{\mathrm{S}} \sum_{\mathrm{j}=1}^{\mathrm{J}}\left[\left(\mathrm{k}_{0 \mathrm{~s}, \mathrm{p}} \mathrm{C}+\mathrm{k}_{0 \mathrm{js}, \mathrm{p}}(\mathrm{E})\right)\right]+\sum_{\mathrm{p}=1}^{\mathrm{N}}\left[\mathrm{k}_{\mathrm{p}}(\mathrm{F})\right]+\mathrm{k}_{\mathrm{f}}(\mathrm{G})+\alpha\right\}+\frac{\mathrm{Q}}{2}\left\{\sum_{\mathrm{p}=1}^{\mathrm{N}+1} \sum_{\mathrm{n}=1}^{\mathrm{NN}} \sum_{\mathrm{h}=1}^{\mathrm{H}}\left[\left(\frac{\mathrm{I}}{\mathrm{k}_{0 \mathrm{~h}, \mathrm{p}}}\right)\right]+\right. \\
& \left.\sum_{\mathrm{p}=1}^{\mathrm{N}+1} \sum_{\mathrm{v}=1}^{\mathrm{V}} \sum_{\mathrm{s}=1}^{\mathrm{S}} \sum_{\mathrm{j}}^{\mathrm{J}}\left[\left(\frac{\mathrm{L}}{\mathrm{k}_{0 \mathrm{v}, \mathrm{p}}}\right)\right]+\sum_{\mathrm{p}=1}^{\mathrm{N}+1} \sum_{\mathrm{s}=1}^{\mathrm{S}} \sum_{\mathrm{j}=1}^{\mathrm{J}}\left[\left(\left(\frac{\mathrm{M}}{\mathrm{k}_{0 \mathrm{~s}, \mathrm{p}}}\right)+\left(\frac{\mathrm{U}}{\mathrm{k}_{0 \mathrm{js}, \mathrm{p}}}\right)\right)\right]+\sum_{\mathrm{p}=1}^{\mathrm{N}}\left[\left(\frac{\mathrm{V}}{\mathrm{k}_{\mathrm{p}}}\right)\right]+\left(\frac{1}{\mathrm{k}_{\mathrm{f}}}\right) \mathrm{X}+\beta\right\}
\end{aligned}
$$

From Eq. (21) the partial derivatives with respect to $\mathbf{k}_{\mathbf{0 h}, \mathbf{p}}, \mathbf{k}_{\mathbf{0 v}, \mathbf{p}}, \mathbf{k}_{\mathbf{0 s , p}, \mathbf{p}}, \mathbf{k}_{\mathbf{0 j s}, \mathbf{p}}, \mathbf{k}_{\mathbf{P}}, \mathbf{k}_{\mathbf{f}}, \mathbf{Q}$ yields:

$$
\begin{aligned}
& \frac{\partial \mathrm{Z}}{\partial \mathrm{k}_{0 \mathrm{~h}, \mathrm{p}}}=\frac{\mathrm{D}}{\mathrm{Q}} \mathrm{A}-\frac{\mathrm{QI}}{2 \mathrm{k}_{0 \mathrm{~h}, \mathrm{p}}{ }^{2}}=0 \Rightarrow \mathrm{k}_{0 \mathrm{~h}, \mathrm{p}}{ }^{*}=\mathrm{Q} \sqrt{\frac{\mathrm{I}}{2 \mathrm{DA}}} \\
& \frac{\partial \mathrm{Z}}{\partial \mathrm{k}_{0 \mathrm{v}, \mathrm{p}}}=\frac{\mathrm{D}}{\mathrm{Q}} \mathrm{B}-\frac{\mathrm{QL}}{2 \mathrm{k}_{0 \mathrm{v}, \mathrm{p}}{ }^{2}}=0 \Rightarrow \mathrm{k}_{0 \mathrm{v}, \mathrm{p}}{ }^{*}=\mathrm{Q} \sqrt{\frac{\mathrm{L}}{2 \mathrm{DB}}} \\
& \frac{\partial \mathrm{Z}}{\partial \mathrm{k}_{0 \mathrm{~s}, \mathrm{p}}}=\frac{\mathrm{D}}{\mathrm{Q}} \mathrm{C}-\frac{\mathrm{QM}}{2 \mathrm{k}_{0 \mathrm{~s}, \mathrm{p}}{ }^{2}}=0 \Rightarrow \mathrm{k}_{0 \mathrm{~s}, \mathrm{p}}{ }^{*}=\mathrm{Q} \sqrt{\frac{\mathrm{M}}{2 \mathrm{DC}}} \\
& \frac{\partial \mathrm{Z}}{\partial \mathrm{k}_{0 \mathrm{js}, \mathrm{p}}}=\frac{\mathrm{D}}{\mathrm{Q}} \mathrm{E}-\frac{\mathrm{QU}}{2 \mathrm{k}_{0 \mathrm{js}, \mathrm{p}}{ }^{2}}=0 \Rightarrow \mathrm{k}_{0 \mathrm{js}, \mathrm{p}}{ }^{*}=\mathrm{Q} \sqrt{\frac{\mathrm{U}}{2 \mathrm{DE}}} \\
& \frac{\partial \mathrm{Z}}{\partial \mathrm{k}_{\mathrm{p}}}=\frac{\mathrm{D}}{\mathrm{Q}} \mathrm{F}-\frac{\mathrm{QV}}{2 \mathrm{k}_{\mathrm{p}}{ }^{2}}=0 \Rightarrow \mathrm{k}_{\mathrm{p}}{ }^{*}=\mathrm{Q} \sqrt{\frac{\mathrm{V}}{2 \mathrm{DF}}} \\
& \frac{\partial \mathrm{Z}}{\partial \mathrm{k}_{\mathrm{f}}}=\frac{\mathrm{D}}{\mathrm{Q}} \mathrm{G}-\frac{\mathrm{QX}}{2 \mathrm{k}_{\mathrm{f}}{ }^{2}}=0 \Rightarrow \mathrm{k}_{\mathrm{f}}{ }^{*}=\mathrm{Q} \sqrt{\frac{\mathrm{X}}{2 \mathrm{DG}}}
\end{aligned}
$$


$\mathrm{Q}^{*}=\sqrt{\frac{2 \mathrm{D} \alpha}{\beta}}$

By substituting the values of $\mathbf{k}_{\mathbf{0 h}, \mathbf{p}}{ }^{*}, \mathbf{k}_{\mathbf{0 v}, \mathbf{p}}{ }^{*}, \mathbf{k}_{\mathbf{0 s , \mathbf { p }}}{ }^{*}, \mathbf{k}_{\mathbf{0 j \mathbf { s }}, \mathbf{p}}{ }^{*}, \mathbf{k}_{\mathbf{p}}{ }^{*}, \mathbf{k}_{\mathbf{f}}{ }^{*}, \mathbf{Q}^{*}$ in Eq. (21) then the relaxed cost function yields:

$$
\begin{aligned}
& \mathbf{T C}_{\mathbf{m}}\left(\mathbf{k}_{\mathbf{0 h}, \mathbf{p}}{ }^{*}, \mathbf{k}_{\mathbf{0 v}, \mathbf{p}}{ }^{*}, \mathbf{k}_{0 \mathbf{s}, \mathbf{p}}{ }^{*}, \mathbf{k}_{0 \mathbf{j s}}{ }^{*}, \mathbf{k}_{\mathbf{p}}{ }^{*}, \mathbf{k}_{\mathbf{f}}{ }^{*}, \mathbf{Q}^{*}\right)=\sqrt{2 \mathrm{D}}\left\{\sum_{p=1}^{N+1} \sum_{n=1}^{N N} \sum_{h=1}^{H}(\sqrt{2 \mathrm{AI}})+\sum_{p=1}^{N+1} \sum_{v=1}^{V} \sum_{s=1}^{S} \sum_{j}^{J}[\sqrt{2 \mathrm{BL}}]\right. \\
& \left.+\sum_{p=1}^{N+1} \sum_{s=1}^{S} \sum_{j=1}^{J}[(\sqrt{2 \mathrm{CM}})+(\sqrt{2 \mathrm{EU}})]+\sum_{\mathbf{p}=1}^{\mathrm{N}}(\sqrt{2 \mathrm{FV}})+\sqrt{2 \mathrm{GX}}+\sqrt{\boldsymbol{\alpha} \boldsymbol{\beta}}\right\}
\end{aligned}
$$

By having such lower bound, one can solve the problem optimally using branch and bound technique with the methodology presented in Rahman and Sarker [28].

\section{CONCLUSIONS}

The goal of this research is to effectively model and minimize the total cost of a multistage supply chain system that is controlled by kanban mechanism and to improve its performance by using milk run method as an efficient freight transportation method that leads to higher utilization of trucks and reduces transportation costs for JIT system. Also supply logistics centres (SLC) is used to overcome the problems associated with long-distance JIT supply chain and it is operated by third party logistics service providers (3PLs) to improve Just-In-Time (JIT) operations. For this supply chain, a proposed nonlinear integer programming (NLIP) model is built and a set of closed-form solutions to batch size and the number of batches in each stage that is to be shipped by kanbans, and the total quantity over one period are to be determined optimally by solving the original problem with relaxed integer constraints to minimize the total cost. This model is expected to increase the efficiency of the production process by reducing the level of wasted materials, time and effort. An application example will be presented during the conference. 


\section{REFERENCES}

[1] Moon, I.K., Cha, B.C., Lee, C.U., "The joint replenishment and freight consolidation of a warehouse in a supply chain". International Journal of Production Economics, vol. 133, no. 1, 2011, pp. 344-350.

[2] Cha, B.C., Moon, I.K., Park, J.H., "The joint replenishment and delivery scheduling of the one-warehouse, n-retailer system". Transportation Research Part E: Logistics and Transportation Review, vol. 44, no. 5, 2008, pp. $720-730$.

[3] Wang, S., Sarker, B.R., "An assembly-type supply chain system controlled by kanbans under a just-in-time delivery policy". European Journal of Operational Research, vol. 162, no. 1, 2005 , pp. 153-172.

[4] Davis, R.A., Demand-driven Inventory Optimization and Replenishment: Creating a More Efficient Supply Chain. Wiley \& SAS Business Series, 2013.

[5] Kaynak, H., "The relationship between just-in-time purchasing techniques and firm performance". Engineering Management, IEEE Transactions, vol. 49, no. 3, 2002, pp. 205-217.

[6] Handfield, R.B., "A resource dependence perspective of Just-in-Time purchasing". Journal of Operations Management, vol. 11, no. 3, 1993, pp. 289-311.

[7] Gunasekaran, A., "Just-in-time purchasing: An investigation for research and applications". International Journal of Production Economics, vol. 59, no. 1, 1999, pp. 77-84.

[8] Chen, Z.X., Sarker, B.R., "Multi-vendor integrated procurement-production system under shared transportation and just-in-time delivery system". Journal of the Operational Research Society, vol. 61, no. 11, 2010, pp. 1654-1666.

[9] Qiu, X., Huang, G.Q., "Supply Hub in Industrial Park (SHIP): The value of freight consolidation". Computers and Industrial Engineering, vol. 65, no. 1, 2013, pp. 16-27.

[10] Nemoto, T., Rothengatter, W., "Efficient Green Logistics in Urban Areas: Milk Run Logistics in the Automotive Industry". Sustainable Transport for Chinese Cities, vol. 3, 2013, pp. 319-337.

[11] Mustafa Tanrikulu, M., Şen, A., Alp, O., "A joint replenishment policy with individual control and constant size orders". International Journal of Production Research, vol. 48, no. 14, 2010, pp. 4253-4271.

[12] Danese, P., Romano, P., Bortolotti, T., "JIT production, JIT supply and performance: investigating the moderating effects". Industrial Management \& Data Systems, vol. 112, no. 3, 2012, pp. 441-465.

[13] Ayers, J. (ed.), Handbook of Supply Chain Management, CRC Press, 2001, pp. 375-383.

[14] Thomas, D.J., Griffin, P.M., "Coordinated supply chain management". European Journal of Operational Research, vol. 94, no. 1, 1996, pp. 1-15.

[15] Wang, S., Sarker, B.R., "A singl-stage supply chain system controlled by kanban under junt-in-time philosophy". Journal of the Operational Research Society, vol. 55, no. 5, 2004, pp. 485-494.

[16] Akturk, M.S., Erhun, F., "An overview of design and operational issues of kanban systems". International Journal of Production Research, vol. 37, no. 17, 1999, pp. 3859-3881. 
[17] Huang, C.-C., Kusiak, A., "Overview of Kanban systems". International Journal of Computer Integrated Manufacturing, vol. 9, no. 3, 1996, pp. 169189.

[18] Kumar, C.S., Panneerselvam, R., "Literature review of JIT-KANBAN system". The International Journal of Advanced Manufacturing Technology, vol. 32, no. 3-4, 2007, pp. 393-408.

[19] Lage Junior, M., Godinho Filho, M., "Variations of the kanban system: Literature review and classification". International Journal of Production Economics, vol. 125, no. 1, 2010, pp. 13-21.

[20] Wang, S., Sarker, B.R., "Optimal models for a multi-stage supply chain system controlled by kanban under just-in-time philosophy". European Journal of Operational Research, no. 1, 2006, pp. 179-200.

[21] Sarker, B.R., Balan, C. V., "Operations planning for a single-stage kanban system operating under linear demand". International Journal of Production Research, vol. 36, no. 2, 1998, pp. 357-375.

[22] Sarker, B.R., Balan, C. V., "Operations planning for a multi-stage kanban system". European Journal of Operational Research, vol. 112, no. 2, 1999, pp. 284-303.

[23] Golhar, D.Y., Sarker, B.R., "Economic manufacturing quantity in a just-intime delivery system". International Journal of Production Research, vol. 30, no. 5, 1992, pp. 961-972.

[24] Sarker, B.R., Parija, G.R., "Optimal batch size and raw material ordering policy for a production system with a fixed-interval, lumpy demand delivery system". European Journal of Operational Research, vol. 89, no. 3, 1996, pp. 593-608.

[25] Sarker, B.R., Parija, G.R., "An Optimal Batch Size for a Production System Operating Under a Fixed-quantity, Periodic Delivery Policy" Journal of the Operational Research Society, vol. 45, no. 8, 1994, pp. 891- 900.

[26] Khan, L.R., Sarker, R.A., "An optimal batch size for a JIT manufacturing system" Computers and Industrial Engineering, vol. 42, no. 2, 2002, pp. 127-136.

[27] Parija, G.R., Sarker, B.R., "Operations planning in a supply chain system with fixed-interval deliveries of finished goods to multiple customers" IIE transactions, vol. 31, no. 11, 1999, pp. 1075-1082.

[28] Rahman, M.A.A., Sarker, B.R., "Supply chain models for an assembly system with preprocessing of raw materials" European Journal of Operational Research, vol. 181, no. 2, 2007, pp. 733-752.

[29] Sarker, R.A., Khan, L.R., "An optimal batch size under a periodic delivery policy". International Journal of Systems Science, vol. 32, no. 9, 2001, pp. 1089-1099.

[30] Sarker, B.R., Jamal, A.M.M., "An optimal batch size for a production a justin-time delivery system". International Journal of Production Economics, vol. 32, no. 2, 1993, pp. 255-260.

[31] Nori, V.S., Sarker, B.R., "Cyclic Scheduling for a Multi-product, Singlefacility Production System Operating Under a Just-in-time Delivery Policy". Journal of the Operational Research Society, vol. 47, no. 7, 1996, pp. 930935.

[32] Silver, E.A., "A simple method of determining order quantities in joint replenishments under deterministic demand". Management Science, vol. 22, no. 12 , 1976, pp. 1351-1361. 
[33] Khouja, M., "Optimizing inventory decisions in a multi-stage multi-customer supply chain". Transportation Research Part E: Logistics and Transportation Review, vol. 39, no. 3, 2003, pp. 193-208.

[34] Cárdenas-Barrón, L.E., "Optimizing inventory decisions in a multi-stage multi-customer supply chain: A note". Transportation Research Part E: Logistics and Transportation Review, vol. 43, no. 5, 2007, pp. 647-654.

[35] Woo, Y.Y., Hsu, S.-L., Wu, S., "An integrated inventory model for a single vendor and multiple buyers with ordering cost reduction" International Journal of Production Economics, vol. 73, no. 3, 2001, pp. 203-215.

[36] Banerjee, A., Banerjee, S., "Coordinated, orderless inventory replenishment for a single supplier and multiple buyers through electronic data interchange" International Journal of Technology Management, vol. 7, no. 4-5, 1992, pp. 328-336.

[37] Çetinkaya, S., Lee, C.Y., "Optimal outbound dispatch policies: Modeling inventory and cargo capacity" Naval Research Logistics (NRL), vol. 49, no. 6, 2002, pp. 531-556.

[38] Çetinkaya, S., Bookbinder, J.H., "Stochastic models for the dispatch of consolidated shipments" Transportation Research Part B: Methodological, vol. 37, no. 8, 2003, pp. 747-768.

[39] Chen, Z., Sarker, B.R., "An integrated optimal inventory lot-sizing and vehicle- routing model for a multisupplier single-assembler system with JIT delivery". International Journal of Production Research, vol. 52, no. 17, 2014, pp. 5086-5114. 